\title{
METODE DIROSATI DALAM MENGEMBANGKAN KEMAMPUAN BACA SEJAK DINI DI TPQ NURUL FALAH BRINGIN LAWANG JENGGAWAH
}

\author{
THE APPLICATION OF DIROSATI METHOD IN DEVELOPING EARLY \\ READING ABILITY IN TPQ NURUL FALAH BRINGIN LAWANG JENGGAWAH
}

\author{
Alivia Intan Permadani \\ Institut Agama Islam Negeri Jember \\ Email: Aliviaintan41@gmail.com \\ Abdul Karim \\ Intitut Agama Islam Negeri Jember \\ karimaldanief@gmail.com
}

\begin{abstract}
ABSTRAK
Metode Dirosati merupakan metode yang paling mudah diterapkan kepada anak-anak usia dini. TPQ Nurul falah adalah salah satu Taman Pendidikan Qur'an yang berada di desa bringin lawang kecamatan jenggawah kabupaten Jember yang menggunakan metode pembelajaran Dirosati, dengan menggunakan metode ini TPQ Nurul Falah berkembang pesat sejak tahun 2002 hingga sekarang dengan jumlah santri kurang lebih 500 orang. Fokus penelitian yang diteliti dalam program Kuliah Kerja nyata dari rumah ini adalah, 1)Bagaimana pelaksanaan metode dirosati dalam meningkatkan kemampuan membaca al-qur'an di TPQ Nurul Falah, 2)Bagaimana evaluasi metode pembelajaran dirosati dalam meningkatkan kemampuan membaca al-qur'an di TPQ Nurul Falah. Tujuan dalam program ini: 1)untuk mendiskripsikan pelaksanaan metode dirosati dalam meningkatkan kemampuan membaca al-qur'an di TPQ Nurul Falah, 2)untuk mendiskripsikan evaluasi metode pembelajaran dirosati dalam meningkatkan kemampuan membaca al-qur'an di TPQ Nurul Falah. Pendekatan yang digunakan dalam penelitian ini yaitu pendekatan kualitatif (Yuridis Empiris) dan akan dikembangkan oleh peneliti dengan desain Studi Kasus yakni menganalisa penerapan metode Dirosati dalam mengembangkan kemampuan baca sejak dini pada anak di TPQ Nurul Falah Bringinlawang Jenggawah, adapun jenis pendekatan dengan metode Triangulasi (Observasi, wawancara dan dokumentasi)
\end{abstract}

Kata Kunci: Dirosati, Metode, Pengembangan, Santri

\section{ABSTRACT}

The Dirosati method is the easiest method to apply to early childhood children. TPQ Nurul Falah is one of the Qur'an Education Parks located in Bringin Lawang Village, Jenggawah District, Jember Regency which uses the Dirosati learning method, using this method TPQ Nurul Falah has grown rapidly since 2002 until now with approximately 500 students. The focus of the research studied in the Real Work Lecture from Home program is, 1) How is the implementation of the dirosati method in improving 
the ability to read al-qur'an in TPQ Nurul Falah, 2) How is the evaluation of the dirosati learning method in improving the ability to read the al-qur'an at TPQ Nurul Falah. The objectives in this program are: 1) to describe the implementation of the dirosati method in improving the ability to read al-quran in TPQ Nurul Falah, 2) to describe the evaluation of the dirosati learning method in improving the ability to read al-quran in TPQ Nurul Falah. The approach used in this research is a qualitative approach (Juridical Empirical) and will be developed by researchers with a case study design, namely analyzing the application of the Dirosati method in developing early reading skills in children at TPQ Nurul Falah Bringinlawang Jenggawah, as for the type of approach using the Triangulation method (Observation, interviews and documentation)

Keywords: Dirosati, Method, Development, Santri

\section{PENDAHULUAN}

Al-Quran sebagai petunjuk ( $h u d a$ ) penerang jalan hidup (bayyinat), pembeda antara yang benar dan yang salah (furqan), penyembuh penyakit hati (syifa), nasihat atau petuah (mau'izah) dan sumber informasi (bayan). Sebagai sumber informasi al-Quran mengajarkan banyak hal kepada manusia: dari persoalan keyakinan, moral, prinsip-prinsip ibadah dan muamalah sampai kepada asas-asas pengetahuan ${ }^{1}$.

Al-Qur'an juga merupakan firman Allah yang mengandung petunjuk dan memberi bimbingan kepada umat manusia dalam menempuh perjalanan hidup, agar selamat didunia dan akhirat. Untuk sebab itu, tiada ilmu yang lebih utama untuk dipelajari oleh seorang muslim melebihi keutamaan mempelajari Al-Qur'an.

Membaca Al-Qur'an merupakan suatu amalan yang berguna pada diri seorang muslim, karena dengan membaca Al-Qur'an seseorang dapat memahami, menghayati serta mengamalkan isi kandungan yang terdapat di dalamnya sehingga dengan demikian pembelajaran Al-Qur'an sudah menjadi tuntutan yang harus dipenuhi oleh setiap individu seorang muslim.

Kepandaian membaca Al-Qur'an tidak lepas dari kegiatan belajar mengajar AlQur'an, baik itu menyangkut metode ataupun perencanaan yang diterapkan. Oleh karena itu, belajar dan mengajar Al-Qur'an merupakan suatu kewajiban suci dan mulia sebagaimana sabda Rasulullah SAW

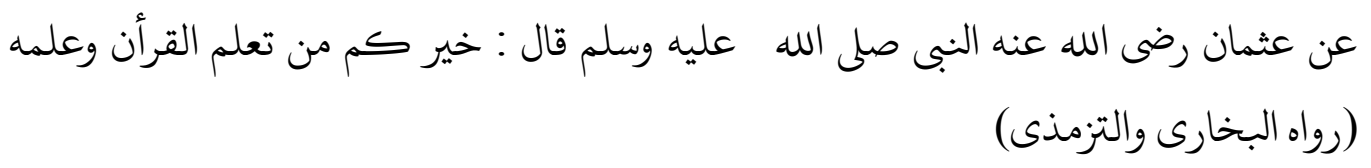

Sebaik-baik kamu adalah orang belajar Al-Qur'an dan mengajarkannya (H.R. Bukhari) ${ }^{2}$

\footnotetext{
${ }^{1}$ Said Agil Husain Almunawar, Aktualisasi Nilai-Nilai Qur'an dalam Sistem Pendidikan Islam, (Ciputat:Ciputat Press, 2005), hlm 5-7

${ }^{2}$ Abu Zakariya, Terjemahan Riyadush Shalihin (Surabaya: Gita Media Press, 2010), hlm 374 
Mengingat pentingnya pembelajaran Al-Qur'an, pada kanak-kanak terkandung potensi belajar yang sangat kuat dan besar. Ia akan sangat peka untuk menangkap sesuatu yang diperintahkan dan diajarkan, oleh sebab itu para ulama' dan ilmuwan Islam mengatakan bahwa pembelajaran Al-Qur'an harus dimulai sejak dini. Untuk merealisasikan hal tersebut diatas tentunya membutuhkan suatu lembaga pendidikan agar yang mengajarkan Al-Qur'an misalnya pondok pesantren, sekolah agama (MI, MTs dan MA), Majlis ta'lim ataupun taman pendidikan Al-Qur'an.

TPQ Nuru Falah adalah salah satu TPQ yang menggunakan metode pembelajaran Dirasati di Jember, dengan menggunakan metode ini TPQ Nurul Falah berkembang dengan pesat karena masyarakat menilai santri dan santriwan mempunyai kelebihan dalam membaca Al-Qur'an daripada TPQ lainnya maka masyarakat sekitar memasukkan anak-anaknya ke TPQ Nurul Falah yang sudah berdiri pada tahun 2002 dengan jumlah santri kurang lebih 100 santri.

Berdasarkan penjelasan di atas peneliti tertarik untuk meneliti penerapan metode pembelajaran Dirasati di TPQ Nurul Falah melalui penelitian berjudul "PENERAPAN METODE DIROSATI DALAM MENGEMBANGKAN KEMAMPUAN BACA SEJAK DINI DI TPQ NURUL FALAH BRINGIN LAWANG JENGGAWAH".

\section{METODE}

Pendekatan yang digunakan dalam penelitian ini adalah pendekatan/ penelitian kualitatif. Pendekatan kualitatif adalah suatu langkah prosedur untuk memahami fenomena tentang apa yang dialami oleh subjek penelitian misalnya perilaku, persepsi, motivasi, tindakan dan lain-lain secara holistic, ${ }^{3}$ Dan di aplikasikan terhadap penerapan metode Dirosati dalam mengembangkan kemampuan baca sejak dini di TPQ Nurul Falah Bringin Lawang Jenggawah.

Jenis Penelitian yang digunakan dalam penelitian ini adalah deskriptif Study kasus, maka Penulis memberikan pengertian bahwa studi kasus (case study) merupakan metode untuk menghimpun dan menganalisis data berkenaan dengan sesuatu kasus, ${ }^{4}$ di dalam Studi kasus peneliti mencoba untuk mencermati individu atau sebuah unit secara mendalam yang terjadi pada proses pembelajaran menggunakan metode Dirosati.

Proses Interview dilakukan secara Bebas Terpimpin kepada responden Kepala TPQ Nurul Falah dan melakukan pengamatan sekaligus semi wawancara kepada responden beberapa Ustadzah Dirosati, Adapun dalam penelitian ini, wawancara yang peneliti lakukan adalah wawancara bebas terpimpin ${ }^{5}$. Karena sebelum diadakan wawancara terlebih dahulu menetapkan masalah dan pertanyaan yang akan diajukan kemudian peneliti menggunakan pertanyaan tersebut sehingga informan akan menjawab dengan keterangan yang panjang. Oleh karena itu kreativitas pewawancara sangat diperlukan untuk mengetahui penerapan

${ }^{3}$ Lexy J Moleong, Metode Penelitian Kualitatif (Bandung: Remaja Rosdakarya, 2005), hlm 6.

${ }^{4}$ Hardani, S.Pd.,M.Si.,dkk, Metode Penelitian Kualitatif \& Kuantitatif (Yogyakarta: Penerbit Pustaka Ilmu, 2020) hlm 64.

${ }^{5}$ Suharsimi Arikunto, Prosedur Penelitian Suatu Pendekatan Praktek (Jakarta: Rineka Cipta, 1998), hlm 146. 
metode Dirosati dalam mengembangkan kemampuan baca sejak dini di TPQ Nurul Falah Bringin Lawang Jenggawah.

Adapun metode pengumpulan data secara TRIANGULASI yang digunakan dalam penelitian ini dihasilkan dari hasil terjun lapang langsung yakni proses wawancara struktural, semi struktural dan hasil pengamatan kepada para responden, dan dilanjutkan dengan dokumentasi kegiatan.

Penulis selalu melakukan evaluasi data yang mana tujuannya tidak lain agar data yang kami peroleh benar-benar valid dengan menggunakan Model (Miles dan Huberman 1992), analisis kualitatif, data yang muncul berwujud kata-kata dan bukan rangkaian angka. Data itu mungkin telah dikumpulkan dalam aneka macam cara yaitu pengamatan terlibat, wawancara, dan selanjutnya diproses melalui perekaman, pencatatan, pengetikan, tetapi analisis kualitatif tetap menggunakan kata-kata yang biasanya disusun ke dalam teks yang diperluas. Serta penulis juga mengikuti kegiatan mengajar metode dirosati di TPQ Nurul Falah.

\section{HASIL DAN PEMBAHASAN}

a. Temuan Lapangan

Pelaksanaan metode pembelajaran Dirosati dalam meningkatkan kemampuan membaca Al Qur'an di TPQ Nurul Falah desa Bringin Lawang kecamatan Jenggawah kabupaten Jember. Kegiatan ini dilaksanakan secara langsung, praktis, dan sederhana sesuai dengan prinsip-prinsip dan kunci-kunci dalam pembelajarn metode Dirosati yang harus diperhatikan ustadz dan ustadzah agar pembelajaran metode Dirosati dapat berjalan secara efektif dan efisien. TPQ Nurul Falah juga telah mengikuti target pencapaian yang ada pada metode Dirosati yang pada setiap jilidnya berbeda-beda.

Sebagai ustadz/ustadzah sekaligus kepala TPQ Nurul Falah mengajar anak diusia dini tidak cukup hanya dengan menyuruhnya untuk membaca, anak diusia dini sangatlah aktif untuk mengenal berbagai macam yang dilakukan salah satunya bermain. Strategi inilah yang membuat mereka lupa akan tujuannya dalam belajar, oleh karena itu sebagai ustadzah perlu memperhatikan bagaimana membuat anak-anak di usia dini bisa lebih baik dalam hal belajar mengaji yang baik untuk kedepannya. Hal ini terlihat dari seiringnya waktu dan komitmen sebagai seorang guru untuk membuat anak didiknya lebih memahami hal baik seperti halnya lebih disiplin. Saya sebagai salah satu peserta KKN-DR sekaligus ustadzah di TPQ Nurul Falah dan di bantu dengan ustadzah lainnya mengupayakan santri-santri untuk lebih baik kedepannya dengan cara :

\section{Melatih kedisiplinan Santri}

Melihat kondisi santri yang cukup banyak dalam satu ruangan tanpa adanya kedisiplinan dari santri dan ustadzah, saya dibantu dengan salah satu ustadzah untuk mengatur bagaimana yang awalnya santri berebut dengan berdesakan untuk maju kedepan agar selesai membaca terlebih dahulu yaitu dengan cara memanggil satu persatu santri dengan urutan tempat mereka duduk. Dengan cara seperti itu mereka bisa lebih baik dan rapi agar terhindar dari rebutan dan berdesakan dengan teman-teman lainnya. Sebelum mereka dipanggil satu persatu kedepan hal yang harus mereka lakukan adalah membaca sendiri ter- 
lebih dahulu sebelum mereka maju membaca kedepan. Cara seperti ini lebih efektif dari sebelumnya.

\section{Membawa buku prestasi}

Ini adalah salah satu cara mudah ustadzah maupun santri mengetahui halaman mereka membaca sudah sampai mana. Buku ini wajib mereka miliki sebagai salah satu koreksi dari kepala TPQ untuk mengetahui kemampuan dari masing-masing santri dalam membaca buku dirosati.

\section{Menulis Buku Camar (cara menulis arab)}

Buku ini adalah salah satu cara mengindari anak yang lebih banyak bermainnya, dari buku ini banyak manfaatnya untuk anak-anak yang awalnya mereka lebih suka bermain sesudah membaca dan tidak bisa menulis arab, justru mereka lebih mengutamakan menulis dan mahir dalam menulis arab. Kegiatan ini sebagai salah satu kedisiplinan bagi anak-anak yang tidak hanya bisa membaca tetapi juga bisa menulis arab.

Dari beberapa cara diatas adalah hasil dari suatu penelitian observasi dan melalui wawancara dengan beberapa ustadzah, agar merubah kebiasaan yang tidak baik menjadi lebih baik bagi anak-anak untuk kedepannya sekaligus untuk kedisiplinan pada kelas selanjutnya.

\section{b. Evaluasi metode pembelajaran Dirosati}

Dalam meningkatkan kemampuan membaca Al-Qur'an di TPQ Nurul Falah desa Bringin Lawang kecamatan Jenggawah kabupaten Jember, Berdasarkan hasil wawancara tentang evaluasi metode pembelajaran Dirosati dalam meningkatkan kemapuan membaca Al-Qur'an desa Bringin Lawang kecamatan Jenggawah kabupaten Jember dilaksanakan dengan menggunakan evaluasi formatif, sumatif dan diagnostik. Evaluasi formatif yaitu evaluasi yang dilakukan selama pelajaran berlangsung dan bisa dengan cara informasi umpan balik dari guru atau siswa. Dan evaluasi ini dilakukan berdasarkan suatu pelajaran yang diberikan, evaluasi yang kedua yaitu evaluasi sumatif yaitu evaluasi yang dilakukan pada program akhir pengajaran misalnya pada akhir semester atau kenaikan jilid, ketiga evaluasi diagnostik dilakukan kapan saja ketika pelajaran berlangsung baik diawal maupun di akhir pelajaran.

Berdasarkan data tersebut dapat dijelaskan bahwa dalam evaluasi metode pembelajaran Dirosati menggunakan evaluasi formatif, sumatif dan diagnostik. Berdasarkan teori bahwa evaluasi formatif adalah penilaian yang dilakukan selama pembelajaran berlangsung. Evaluasi sumatif adalah dilakukan pada akhir program pengajaran yaitu pada akhir semester atau akhir tahun pelajaran. Evaluasi diagnostik adalah penilaian yang mengungkapkan kesulitan-kesulitan peserta didik. Proses ini dapat dilakukan kapan saja, baik pada waktu permulaan proses pembelajaran, selama proses pembelajaran ataupun diakhir proses pembelajaran. Berdasarkan teori evaluasi tersebut, di TPQ Nurul Falah dalam pembelajaran 
menggunakan evaluasi tersebut sehingga dapat mengetahui dengan cepat kemampuan santri dalam membaca Al-Qur'an.

Adapun observasi yang saya temui mengenai teknik cara evalusi santri dengan cara turun langsung disetiap masing-masing kelas serta melalui berbagai wawancara kepada kepala TPQ Nurul Falah bahwa teknik evaluasi ini dilakukan sama rata hanya berbeda teknik dalam pengujiannya, seperti halnya yaitu:

\section{Evaluasi Dasar}

Evaluasi dasar ini mewawancarai langsung kepada salah satu ustadzah Kelas satu dan dua yaitu membaca makhorizul huruf dilakukan secara mengulang dari halaman depan hingga belakang sebanyak dua kali, dilanjut dengan ujian naik tingkat jilid atas yang diujikan kepada kepala TPQ.

\section{Evaluasi Tengah}

Evalusi tengah ini mewawancarai langsung kepada salah satu ustadzah Kelas tiga dan empat yaitu dengan mengujikan panjang pendeknya bacaan secara mengulang dari halaman depan hingga belakang sebanyak dua kali, dilanjut dengan ujian naik tingkat jilid atas yang diujikan kepada kepala TPQ.

\section{Evaluasi Atas}

Evaluasi yang terakhir ini melakukan wawancara kepada ustadzah kelas lima sekaligus kepada kepala TPQ yang kebetulan mengajar santri kelas enam yaitu mengujikan tajwid dan bacaan al qur'an dengan benar, dilanjut dengan ujian tahapan-tahapan selama 6 bulan untuk naik kelas Diniah yang ditangani langsung oleh kepala TPQ.

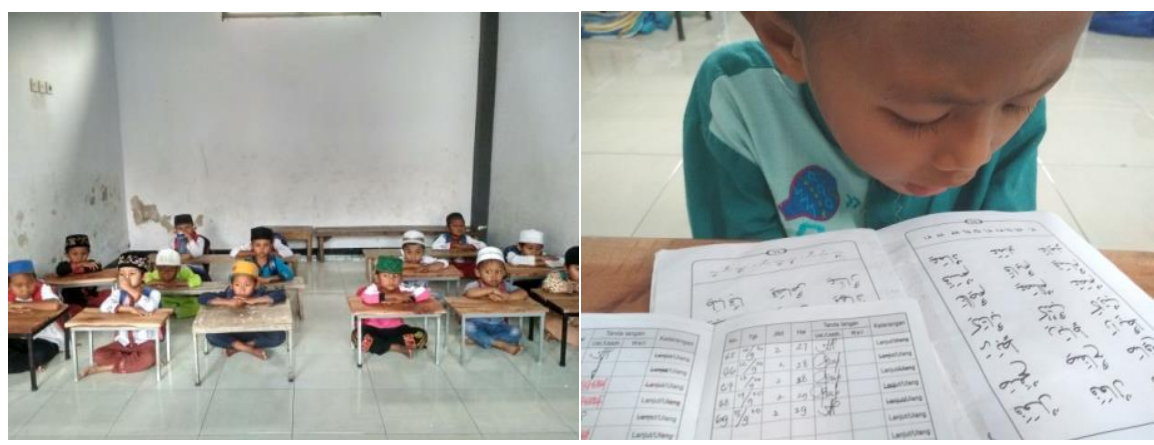

(a)

(b)

Ket 1: proses doa bersama untuk mengawali kegiatan belajar

Ket 2: Membaca Buku Dirosati Jilid II sesuai dengan halaman yang tertulis di buku prestasi

Metode mengajar adalah suatu pengetahuan tentang cara- cara mengajar yang digunakan oleh seorang guru atau insruktur. Tekhnik penyajian yang dikuasai oleh guru untuk mengajar atau menyajikan bahan pelajaran kepada siswa didalam kelas baik secara individual, kelompok atau klasikal agar pelajaran itu diserap, dipahami dan dimanfaatkan 
oleh siswa dengan baik. ${ }^{6}$ Setiap metode pembelajaran yang digunakan bertalian dengan tujuan belajar yang ingin dicapai. Tujuan untuk mendidik santri agar sanggup memecahkan masalah-masalah dalam belajarnya, memerlukan metode yang mendorong keberhasilan ustadz/ustadzah dalam proses belajar mengajar, ustadz/ustadzah seharusnya mengerti akan fungsi dan langkah-langkah pelaksanaan metode mengajar. Metode mengajar dalam metode Dirosati adalah:

a. Individual / privat

Individual atau privat adalah mengajar dengan memberikan materi pelajaran santri per santri sesuai dengan kemampuannya menerima pelajaran. Sehingga dengan demikian, strategi mengajar individual /privat adalah proses belajar mengajar yang dilakukan dengan cara satu persatu (secara individu) sesuai dengan materi pelajaran yang dipelajari atau dikuasai santri. Pada waktu menunggu giliran belajar secara individu, maka santri yang lain diberi tugas menulis lamar (latihan menulis arab).

b. Klasikal-individual

Klasikal adalah mengajar dengan cara memberikan materi pelajaran secara masal (bersama-sama) kepada sejumlah santri dalam satu kelompok/kelas. Tujuan pembelajaran sistem klasikal individual:

1. Agar dapat menyampaikan seluruh pelajaran secara garis besar dan prinsip-prinsip yang mendasarinya.

2. Memberi motivasi (dorongan semangat belajar) dan minat perhatian santri untuk belajar. Strategi klasikal-individual adalah proses belajar mengajar yang dilakukan dengan cara sebagian waktu untuk klasikal dan sebagian waktu lainnya untuk individual. Dan tekhnik mengajar klasikal individual yaitu:

(a) 10-15 menit = mengajar secara klasikal

(1) Untuk mengajar beberapa pokok pelajaran atau halaman buku Dirosati.

(2) Untuk mengajar materi pelajaran yang sulit dipahami/dikuasai oleh santri.

(3) Untuk mengulangi beberapa materi pelajaran bagi santri yang kurang lancar.

(b) 45-50 menit = mengajar secara individual

Untuk mengetahui kelancaran santri dilakukan evaluasi secara individu. Strategi ini untuk mengetahui apakah santri mampu mengikuti kelas jilid selanjutnya.

(c) Klasikal baca simak

Metode ini digunakan untuk mengajarkan membaca dan menyimak bacaan Al-Qur'an orang lain. Dasar yang digunakan adalah firman Allah SWT dalam Al-Qur'an surat Al A'raf ayat 204:

Artinya: 'Dan apabila dibacakan Al Qur'an, maka dengarkanlah baik-baik, dan perhatikanlah dengan tenang agar kamu mendapat rahmat". 7

Metode klasikal baca simak dilakukan dengan cara:

1) Membaca bersama-sama atau klasikal

2) Pergantian membaca secara individu atau kelompok, santri yang lain menyimak. ${ }^{8}$

c. Media.

\footnotetext{
${ }^{6}$ Ahmadi, Strategi Belajar Mengajar (Bandung: Pustaka Setia, 1997), hlm 52

${ }^{7}$ Depag RI, Al Qur'an dan Terjemahannya (Jakarta: Surya Cipta Aksara Surabaya, 1993), 256

${ }^{8}$ Kholilah, Interview dengan Kepala TPQ Nurul Falah Bringin Lawang Jenggawah, Jember, 10 Agustus 2020
} 
Media berasal dari bahasa latin yang merupakan bentuk jamak dari "medium" yang secara harfiah berarti perantara atau pengajar. Makna umumnya adalah segala sesuatu yang dapat menyalurkan informasi. Istilah media populer dalam bidang komunikasi sehingga media yang digunakan dalam pembelajaran disebut media pembelajaran.

Media pembelajaran merupakan wadah dari pesan yang oleh sumber atau penyalurnya ingin diteruskan kepada sasaran atau penerima pesan. Dengan demikian posisi media selalu berada diantara komunikator dan komunikan, antara sumber pesan dan penerima pesan. Dengan adanya media, materi-materi yang bersifat abstrak dapat dijadikan lebih konkret. $^{9}$

Dalam makna yang demikian maka media bisa dikonotasikan dengan istilah alat, dalam pendidikan alat didefinisikan sebagai sesuatu yang dapat digunakan dalam mencapai tujuan, alat tidak hanya sebagai pelengkap tetapi juga sebagai pembantu mempermudah usaha mencapai tujuan. Penggunaan tidak lain adalah untuk mengurangi verbalisme agar anak didik mudah memahami bahan pelajaran yang disajikan. Penggunaan media tidak tepat akan membawa akibat pada pencapaian tujuan pengajaran kurang efektif dan efisien. Untuk itu, ustadz/usadzah harus terampil memiliki media agar tidak mengalami kesukaran dalam menunaikan tugas.

Dalam kegiatan edukatif biasanya dipergunakan alat non material, alat material, alat non material berupa suruhan, perintah, larangan, nasihat, dan sebagainya. Sedangkan alat material atau alat bantu pengajaran berupa papan tulis, kapur, gambar, diagram, lukisan, video, dan sebagainya. Dengan demikian pengguna media dalam proses interaksi belajar mengajar sangat penting, seorang ustadz/usadzah dapat menggunakan media material maupun non material agar dalam proses belajar mengajar dapat mencapai tujuannya secara efektif dan efisien. Untuk itu keterampilan ustadz/ usadzah dalam pemilihan media harus yang baik dan benar.

Ustadz/usadzah dalam menggunakan media dalam mengajar khususnya pelajaran Al-Qur'an melalui metode Dirosati ini selain menggunakan buku Dirosati juga membutuhkan alat bantu diantaranya papan tulis, kapur, gambar yang berkaitan dengan pembelajaran Al-Qur'an, sehingga dengan pemakaian alat pengajaran tersebut santri merasa senang dan tidak bosan dengan materi yang disampaikan bervariasi.

\section{d. Pelaksanaan Pembelajaran Metode Dirosati}

Pelaksanaan pembelajaran adalah interaksi guru dan siswa dalam rangka menyampaikan bahan pelajaran kepada siswa dan untuk mencapai tujuan pembelajaran. Dari definisi tersebut diketahui bahwa dalam proses pembelajaran terdapat beberapa unsur diantaranya adalah pembelajaran sebagai sebuah proses yang bertujuan untuk membelajarkan siswa di dalam kelas. Dalam kegiatan pembelajaran terjadi proses interaksi yang bersifat edukatif antara guru dengan siswa. Kegiatan yang dilaksanakan tersebut bermuara pada satu tujuan yaitu untuk mencapai tujuan pembelaaran yang ditetapkan sebelumnya. ${ }^{10}$ Dalam pelaksanaan pengajaran, ustadz/usadzah melaksanakan aktivitas interaksi belajar mengajar dengan berpedoman pada persiapan mengajar yang telah dibuat. Pemberian bahan pelajaran disesuaikan dengan urutan yang telah diprogramkan secara sistematis dalam tahap persiapan. Dalam proses interaksi belajar mengajar, meski persiapan mengajar telah dipersiap-

${ }^{9}$ Sugeng Listyo, Perencanaan Pembelajaran (Malang: UIN Maliki Press, 2010), hlm 118

10 Edy B Mulyana, "Pengertian Kegiatan Pembelajaran", http://gurusejatiku. blogspot.co.id/2015/01/pengertian-kegiatan-pembelajaran.html?m=1 (25 Agustus 2020) 
kan sebagai langkah awal, namun ustadz/usadzah tetap memperhatikan prinsip- prinsip mengajar. Hal-hal yang harus diperhatikan oleh ustadz/ustdzah dalam mengajar Al Qur'an metode Dirosati ini adalah sebagai berikut :

1. Prinsip-Prinsip Metode Dirosati

Menurut kepala madrasah TPQ Nurul Falah Ustadzah Kholilah agar dapat berhasil dalam menerapkan pengajaran metode Dirosati ada beberapa prinsip dasar yang harus diperhatikan oleh ustadz/usadzah maupun santri antara lain $:^{11}$

1.) Prinsip yang harus dipegang oleh ustadz/usadzah

a. DAKTUN (tidak boleh menuntun) dalam hal ini ustadz/ustadzah hanya menerangkan pokok pelajaran, memberikan contoh yang benar, menyuruh santri membaca sesuai dengan contoh, menegur bacaan yang salah, menunjukkan kesalahan bacaan dan memberitahukan seharusnya bacaan yang benar.

b. TIWAGAS (teliti, waspada, dan tegas)

Teliti artinya dalam memberikan contoh atau menyimak ketika santri membaca jangan sampai ada yang salah walaupun sepele. Waspada artinya dalam memberikan contoh atau menyimak santri benar-benar diperhatikan ada rasa sambung dari hati ke hati. Tegas artinya dalam memberikan penilaian ketika menaikkan halaman atau jilid tidak boleh banyak toleransi, ragu-ragu ataupun segan, penilaian yang diberikan benar-benar obyektif.

2.) Prinsip yang harus dipegang oleh santri

a. Cara Belajar Santri Aktif dan Mandiri

Santri dituntut keaktifan, konsentrasi dan memiliki tanggung jawab terhadap dirinya tentang bacaan Al-Qur'annya. Sedangkan ustadz/ustadzah sebagai pembimbing, motivator dan evaluator saja. Cara belajar santri aktif perlu dipertimbangkan untuk lebih mengembangkan potensi- potensi santri secara individual, dalam hal ini ustadz/ustadzah bertugas memberikan bimbingan dan pengarahan kepada santri secara aktif. Untuk itu diharapkan yang aktif tidak hanya santrinya tetapi juga ustadz/ustadzahnya.

b. Lancar Cepat Tepat dan Benar

Lancar artinya bacaannya tidak ada yang mengulang-ulang. Cepat artinya bacaannya tidak ada yang putus-putus atau mengeja. Tepat artinya dapat membunyikan sesuai dengan bacaan dan dapat membedakan antara bacaan yang satu dengan lainnya. Benar artinya hukum-hukum bacaan tidak ada yang salah.

2. Kunci-Kunci dalam penyampaian Metode Dirosati

a.) Praktis

Artinya: langsung (tidak dieja).

Contoh: dibaca A-BA (bukan Alif fathah A, BA fatha BA) dan dibaca pendek. Jangan dibaca panjang Aa Baa atau Aa Ba atau A Baa.

b.) Sederhana

Artinya : kalimat yang dipakai untuk menerangkan usahakan sederhana asal dapat difahami, cukup memperhatikan bentuk huruf nya saja, jangan menggunakan

${ }^{11}$ Kholilah, Interview dengan Kepala TPQ Nurul falah Bringin Lawang Jenggawah, Jember, 13 agustus 2020 
keterangan yang teoritis/devinitif. Contoh bunyinya = BA, cukup katakan: Perhatikan titiknya! ini BA, ini TA, dan ini TSA.

c.) Sedikit demi sedikit

Mengajar Dirosati tidak boleh terburu-buru, ajarkan sedikit demi sedikit asal benar, jangan menambah pelajaran baru sebelum bisa dengan lancar, bacaan terputusputus. Ustadz/ustadzah yang kelewat toleransi terhadap santri dengan mengabaikan disiplin petunjuk ini akibatnya akan berantakan, sebab pelajaran yang tertumpuk dibelakang menjadi beban bagi santri, ia justru bingung dan kehilangan gairah belajar. Jika disuruh mengulang dari awal jelas tidak mungkin, ia akan malu, dan akhirnya ia akan enggan pergi belajar. Ustadz/ustadzah yang disiplin dalam menaikkan pelajaran hasilnya akan menyenangkan santri itu sendiri, semakin tinggi jilidnya semakin senang, karena ia yakin akan kemampuannya, dan insyaAllah akan tambah semangat menuntaskan pelajarannya. Disiplin ini memang mengundang reaksi besar baik dari santri maupun wali santri, oleh karenanya ustadz/ustadzah dituntut dapat berpegang teguh, tidak kehilangan cara dengan mengorbankan disiplin tersebut. Disinilah perlu adanya seni mengajar itu.

\section{d.) Tidak Menuntun Untuk Membaca}

Seorang ustadz/ustadzah cukup menerangkan dan membaca berulang-ulang pokok bahasan pada setiap babnya sampai santri mampu membaca sendiri tanpa dituntun latihan dibawahnya. Metode ini bertujuan agar santri faham terhadap pelajarannya, tidak sekedar hafal. Karena itu ustadz/ustadzah ketika mengetes kemampuan santri boleh dengan cara melompat-lompat, tidak urut mengikuti baris tulisan yang ada Apabila dengan sangat terpaksa ustadz/ustadzah harus dengan menuntun, maka dibolehkan dalam batas 1 sampai 2 kata saja.

e.) Waspada Terhadap Bacaan Yang Salah

Santri lupa terhadap pelajaran yang lalu itu soal biasa dan wajar, santri lupa dan ustadz/ustadzah diam itulah yang tidak wajar. Terlalu sering santri membaca salah saat ada ustadz/ustadzah dan ustadz/ustadzahnya diam saja, maka bacaan salah itu akan dirasa benar oleh santri, dan salah merasa benar itulah bibit dari salah kaprah. Maka agar ini tidak terus menerus terjadi dalam bacaan Al-Qur'an, maka harus waspada setiap ada santri baca salah tegur langsung, jangan menunggu sampai bacaan berhenti. Kewaspadaan inilah cara satu-satunya memberantas salah kaprah itu. Keberhasilan ustadz/ustadzah mengajar tartil dan fashih adalah tergantung pada peka atau tidaknya guru mendengar anak baca salah.

f.) Drill (bisa karena biasa)

Metode drill banyak tersirat pada buku Dirosati, adapun yang secara khusus menggunakan metode ini adalah pada pelajaran:

1. Ghorib

2. Ilmu Tajwid

3. Hafalan-hafalan.

Biarpun tanpa ada kewajiban menghafal dirumah, insyaAllah dengan metode drill ini semua pelajaran hafalan akan hafal dengan sendirinya.

3. Evaluasi pembelajaran Metode Dirosati 
Evaluasi merupakan penilaian tingkat keberhasilan santri mencapai tujuan yang telah ditetapkan dalam sebuah program. Dalam fungsinya sebuah penilaian hasil belajar santri, ustadz/ustadzah hendaknya terus menerus mengikuti hasil belajar yang telah dicapai oleh santri dari waktu ke waktu. Informasi yang diperoleh melalui evaluasi ini merupakan umpan balik (feed back) terhadap proses belajar megajar. Umpan balik ini akan dijadikan titik tolak untuk memperbaiki dan meningkatkan proses belajar mengajar selanjutnya. Dengan demikian proses belajar mengajar terus menerus ditingkatkan untuk memperoleh hasil yang optimal. Evaluasi dapat dibagi menjadi beberapa bagian sebagaimana yang ditulis oleh Jihan dan Haris. ${ }^{12}$ Diantaranya :

1. Penilaian Formatif

Penilaian formatif dilakukan selama pembelajaran berlangsung bisa dengan cara memberikan informasi yang berupa umpan balik baik bagi guru atau siswa. Bagi guru umpan balik tersebut dapat dipakai sebagai perbaikan pembelajaran yang telah dilaksanakan. Sedangkan bagi peserta didik umpan balik yang diterima akan memberikan informasi kepada guru apakah standar kompetensi dan kompetensi dasar telah dicapai dengan baik atau tidak, sehingga dapat dilakukan perbaikan-perbaikan dalam pembelajaran apabila kompetensi yang diinginkan tidak tercapai dengan baik.

\section{Penilaian Sumatif}

Tes sumatif dilakukan pada akhir program pengajaran yaitu pada akhir semester atau akhir tahun pelajaran. Tes ini dilakukan untuk mengetahui sejauh mana pengetahuan, sikap serta keterampilan yang dikuasai oleh peserta didik, apakah telah sesuai dengan tujuan atau belum.

\section{SIMPULAN}

Berdasarkan hasil penelitian sebagaimana telah diuraikan diatas baik yang bersifat teoritik maupun praktis, maka untuk memberikan pemahaman yang lebih singkat tepat dan terarah dapat ditarik beberapa kesimpulan antara lain sebagai berikut :

Pelaksanaan metode pembelajaran dirosati dalam meningkatkan kemampuan membaca Al-Qur'an di TPQ Nurul Falah desa Bringin Lawang kecamatan Jenggawah kabupaten Jember, Dilaksanakan sesuai perencanaan awal dari pembelajaran, hal tersebut dapat dilihat dari sistematika pembelajaran para asatidz yang telah memperhatikan prinsip-prinsip dan kunci-kunci dalam penyampaian metode Dirosati serta dalam pembelajarannya telah memenuhi target pencapaian yang ada pada metode Dirosati.

Evaluasi metode pembelajaran dirosati dalam meningkatkan kemampuan membaca Al-Qur'an di TPQ Nurul Falah Muna desa Bringin Lawang kecamatan Jenggawah kabupaten Jember menggunakan evaluasi formatif dan sumatif sehingga dapat mengetahui kemampuan santri dalam membaca Al- Qur'an.

\section{DAFTAR PUSTAKA}

Said Agil Husain Almunawar, Aktualisasi Nilai-Nilai Qur'an dalam Sistem Pendidikan Islam, (Ciputat:Ciputat Press, 2005)

Abu Zakariya, Terjemahan Riyadush Shalihin (Surabaya: Gita Media Press, 2010)

${ }^{12}$ Abdul Jihan, Asep dan Haris, Evaluasi Pembelajaran (Yogyakarta : Multi Pressindo, 2008), hlm 56-57 
Tim penyusun cabang ma'arif jember, buku petunjuk praktis mengajar dirosati, (Jember, LP ma'arif, 2004)

Ahmadi, Strategi Belajar Mengajar (Bandung: Pustaka Setia, 1997)

Sugeng Listyo, Perencanaan Pembelajaran (Malang: UIN Maliki Press, 2010)

Abdul Jihan, Asep dan Haris, Evaluasi Pembelajaran (Yogyakarta : Multi Pressindo, 2008)

Edi B Mulyana,"pengertian Kegiatan pembelajaran", http://gurusejatiku.blogspot.co.id/2015/01/pengertian-kegiatan pembelajaran. Html?m= 